\title{
KORUPSI DALAM KAJIAN HUKUM DAN HAK ASASI MANUSIA
}

\section{Pricilia Ryana}

Mahasiswa Fakultas Hukum, Universitas Negeri Semarang

Surel: priciliarryana@gmail.com

\section{Aisy Idzati}

Mahasiswa Fakultas Hukum, Universitas Negeri Semarang

Surel: aisyidzati@students.unnes.ac..id

\begin{abstract}
ABSTRAK
Hubungan antara Korupsi dan Hak Asasi Manusia (HAM) nampaknya belum begitu banyak dibicarakan dikalangan akademisi dan praktisi, bahkan belum begitu banyak literatur atau buku teks tentang hal ini. Ini mungkin disebabkan oleh karena substansi korupsi atau tindak pidana korupsi secara tekstual tidak menyinggung secara langsung hubungan substantif korupsi dengan HAM. Fenomena korupsi telah menghasilkan kemiskinan, rendahnya tingkat pendidikan dan kesehatan, serta buruknya pelayanan publik. Dan akibat dari korupsi penderitaan selalu dialami oleh masyarakat terutama masyarakat kecil yang berada di bawah garis kemiskinan.
\end{abstract}

RIWAYAT ARTIKEL

Article History

Diterima 21 Maret 2017

Dipublikasi 20 November 2018

\section{KATA KUNCI}

Keywords

Hak Asasi Manusia, HAM, Korupsi, Korupsi Politik

\section{HOW TO CITE (saran perujukan):}

Ryana, P., \& Idzati, A. (2018). "Korupsi dalam Kajian Hukum dan Hak Asasi Manusia", Lex Scientia Law Review. Volume 2 No. 2, November, hlm. 195-206.

\section{PENDAHULUAN}

Fenomena korupsi sudah ada sejak manusia mulai menata kehidupannya dalam bentuk organisasi-organisasi yang teratur. Insentitas korupsi berbeda-beda waktu dan tempatnya, seperti problem sosial lainnya, korupsi sangat ditentukan oleh berbagai faktor di luarnya. Pada awalnya catatan korupsi menunjuk pada persoalan penyuapan kepada para hakim dan tingkah laku para pejabat pemerintah, yang mula-mula dianggap sebagai perbuatan korupsi. Semakin berkembangnya masyarakat dan organisasi negara, korupsi juga mengalami evolusi dari satu fase kehidupan ke fase kehidupan lainnya. Hampir disemua negara 
ditemukan adanya korupsi, walaupun dengan intensitas yang berbeda satu dengan yang lainnya, sehingga ada yang mengatakan bahwa suatu pemerintahan akan tumbang bila perbuatan korupsi tidak diberantas. Perilaku korupsi tidak saja terdapat di negara demokrasi saja, dalam negara diktator militer juga korupsi ada. Dalam setiap tahapan pembangunan dari segala sistem ekonomi, dari negara kapitalis terbuka seperti Amerika Serikat, sampai pada ekonomi yang direncanakan secara terpusat seperti terdapat dibekas Negara Uni Soviet sekalipun. Fenomena ini telah menghasilkan kemiskinan, rendahnya tingkat pendidikan dan kesehatan, serta buruknya pelayanan publik. Dan akibat dari korupsi penderitaan selalu dialami oleh masyarakat terutama masyarakat kecil yang berada di bawah garis kemiskinan. Sekarang saja dibeberapa daerah dari berita-berita di media cetak maupun elektronik, kita bisa membaca dan melihat bahwa banjir, longsor, infrastruktur hancur, taransportasi terganggu, distribusi barang-barang terhambat, kesehatan masyarakat terpuruk dan semuanya ini merupakan efek dari adanya korupsi, yang mau tidak mau dampaknya dirasakan oleh masyarakt kecil yang tidak berdosa.

Pembicaraan mengenai hubungan antara Korupsi dan Hak Asasi Manusia (HAM) nampaknya belum begitu banyak dibicarakan dikalangan akademisi dan praktisi, bahkan belum begitu banyak literatur atau buku teks tentang hal ini. Ini mungkin disebabkan oleh karena substansi korupsi atau tindak pidana korupsi secara tekstual tidak menyinggung secara langsung hubungan substantif korupsi dengan HAM. Padahal korelasi keduanya sangat jelas, karena hampir dalam semua kasus korupsi, secara langsung maupun tidak langsung akan diikuti oleh pelanggaran HAM. Perbuatan korupsi selalu berawal dari adanya penyalahgunaan kekuasaan, artinya pelaku korupsi biasanya dilakukan oleh para pemegang kekuasaan. Dengan kata lain, bahwa perbuatan menyimpang yang dilakukan oleh aparat birokrasi dalam bentuk korupsi, dapat membuat kesengsaraan bagi rakyat kecil disuatu negara. Itu artinya dengan perbuatan korupsi telah terjadi perampasan terhadap hak-hak masyarakat atas hak ekonomi, sosial dan budaya, itu berarti telah terjadi pelanggarn HAM.

\section{Rumusan Masalah}

1. Apakah korupsi merupakan pelanggaran HAM?

2. Bagaimana Korupsi dalam kajian Hukum dan HAM?

3. Bagaimana Korelasi Korupsi Politik dengan Hak Asasi Manusia?

\section{Metode Penulisan}

1. Jenis Penelitian 
Jenis penelitian dalam tulisan ini menggunakan jenis yuridisnormatif, karena masih banyak masyarakat yang tidak mengetahui bahwa Pencabutan hak merupakan pidana tambahan yang diatur dalam KUHP dan UU Tipikor serta dalam perspektif hak asasi manusia juga diatur mengenai hak pilih aktif dan pasif.

2. Pendekatan Penelitian

Pendekatan Penelitian pertama adalah pendekatan Undang-Undang (statute approach), mengkaji semua undang-undang yang bersangkut paut dengan pencabutan hak pilih aktif dan pasif terhadap terpidana tindak pidana korupsi.

\section{PEMBAHASAN}

\section{A. Hubungan Antara korupsi dan Hak Asasi Manusia}

Di dalam pendahuluan telah disinggung bagaimana persoalan korupsi dapat menjadi persoalan yang sangat luas, yaitu tidak hanya menjadi persoalan hukum tetapi juga telah menjadi persoalan ekonomi dan sosial bangsa, sehingga apabila itu dibiarkan dapat mengakibatkan persoalan pelanggaran hak asasi manusia.

Apabila kita menilik dari semangat Deklarasi PBB tentang human right, maka di sana telah diakomodir tentang hak asasi manusia yang sangat penting, yaitu bahwa hak asasi manusia adalah(Perhimpunan Bantuan Hukum dan HAM Indonesia Jawa Barat, 2003) "Semua hak yang dibutuhkan setiap orang sebagai manusia. Secara garis besar maka hak asasi manusia dibagi atas dua rumpun, yaitu hak-hak sipil dan politik, serta hak-hak ekonomi, sosial, dan budaya. Kedua penggolongan ini memiliki kedudukan yang sangat penting, karena sangat dibutuhkan oleh manusia".

Apabila persoalan korupsi sekarang merupakan persoalan pelanggaran HAM, maka perlakuan terhadap perbuatan ini juga harus sama dengan perlakuan terhadap pelanggaran-pelanggaran HAM lainnya, walaupun perbuatannya secara langsung tidak sama dengan perbuatan pelanggaran HAM yang ada, yaitu seperti genosida, atau seperti pembunuhan masal. Tetapi dampak atau akibat dari perbuatan korupsi secara tidak langsung dan secara terus menerus (sistemik) dapat membunuh manusia, sehingga pelaku korupsi dapat dikategorikan sebagai pelaku kejahatan luar biasa atau yang sering disebut dengan istilah pelaku Extra Ordinary Crimes.

Penanganan terhadap pelaku kejahatan yang luar biasa harus dilakukan dengan sangat luar biasa, yaitu perangkat undang-undangnya harus dapat memadai (dapat menjangkau segala perbuatan korupsi dalam berbagai jenis dan berbagai tingkatan), perangkat pelaksana undang-undangnya juga harus orang-orang yang terpilih, yaitu orang-orang yang sangat professional dalam bidang itu dan beresih dari korupsi, termasuk budaya hukumnya (kesadaran hukum masyarakat) harus dapat mendukung terlaksananya persoalan tersebut. 
Indonesia sekarang ini sedang berusaha melaksanakan itu, hal itu dapat dibuktikan dengan terus dilakukannya amandemen terhadap pertauran perundangundangan yang mengatur masalah korupsi, yaitu dari mulai perubahan terhadap Peraturan Penguasa Militer No. PRT/PM/06/1975 oleh Peraturan Penguasa Perang Pusat AD No. PRT/PEPERPU/03/1958, selanjutnya diubah dengan UU No. 24/Prp/1960, selanjutnya diubah dengan UU No. 3 Tahun 1971, selanjutnya pada era pemerintahan Presiden Megawati Soekarnoputri, maka Undang-undang No. 3 Tahun 1971 diubah dengan Undang-undang No. 31 Tahun 1999 tentang Pemberantasan Tindak Pidana Korupsi, dan sebagai penyempurnaan dari undangundang di atas, maka dilengkapi dengan Undang-undang No. 20 Tahun 2001.

Di dalam Undang-undang Tindak Pidana Korupsi No. 31 Tahun 1999 terdapat 4 (empat) pembaruan mendasar, yaitu: (M. Yahya Harahap, 2002:68-69)

1. Tindak pidana korupsi telah dirumuskan secara formal, yaitu meskipun hasil korupsi telah dikembalikan kepada negara, pelaku tindak pidana korupsi tetap dituntut dan diajukan ke siding pengadilan dan dapat dipidana (diberi sanksi pidana);

2. dianutnya sistem pembuktian terbalik murni yang mewajibkan kepada terdakwa di muka siding pengadilan untuk membuktikan bahwa harta kekayaannya bukan dari hasil korupsi. Jika ia dapat membuktikan bahwa harta kekayaannya bukan dari hasil korupsi, dan hakim yakin atas bukti-bukti yang diajukannya, maka terdakwa dibebaskan. Sebaliknya jika ia tidak dapat membuktikannya dan hakim yakin bahwa terdakwa bersalah atas perbuatannya, maka ia dijatuhi pidana yang bervariasi,paling singkat 1 (satu) tahun sampai dengan 3 (tiga) tahun, dan paling lama antara 10 tahun atau 15 tahun atau pembuktian menurut KUHP yang selama ini dianut dalam proses peradilan pidana kurang lebih 20 tahun yang lalu;

3. Pemberian uang di atas jumlah tertentu (Rp. 10.000.000,-) harus dianggap suap, kecuali dapat dibuktikan sebaliknya. Dalam kaitan ini maka perbuatan suap sudah merupakan delik formil.

4. Penyitaan atas harta kekayaan terdakwa dapat dilaksanakan baik sebelum maupun sesudah dijatuhkannya putusan pengadilan dan tidak dibatasi oleh masa daluwarsa.

Selanjutnya di tingkat perangkat pelaksana undang-undang, maka sekarang telah dibentuk suatu lembaga penyidik tindak pidana korupsi, yang memiliki wewenang sebagai petugas penyidik dan penuntut pelaku tindak pidana yaitu Komisi Pemberantasan Korupsi (KPK). Dan yang terakhir yang harus diperhatikan adalah budaya hukum, hal ini sangat penting dikarenakan bahwa penanggulangan korupsi tidak akan berhasil tanpa adanya dukungan dan kesadaran hukum masyarakat, seperti yang dikemukakan oleh Sudarto,bahwa: (Arief, 2003: 
87) Suatu clean government dimana tidak terdapat atau setidaknya tidak banyak terjadi perbuatan-perbuatan korupsi, tidak bias diwujudkan hanya dengan peraturan-peraturan hukum, meskipun itu hukum pidana dengan sanksi yang tajam. Jangkauan hukum pidana adalah terbatas.

\section{B. Korupsi dalam Kajian Hukum dan HAM}

Salah satu materi yang diatur dalam UUD NRI Tahun 1945 adalah mengenai jaminan terhadap perlindungan hak-hak asasi manusia warga negara. Dalam hal ini, yang menjadi pertanyaan adalah, mengapa masalah HAM menjadi salah satu materi yang dimuat di dalam konstitusi atau Undang-Undang Dasar? Jawaban atas pertanyaan ini adalah karena negara sebagai organisasi kekuasaan cenderung untuk menyalahgunakan kekuasaan tersebut, oleh sebab itu untuk memberikan jaminan perlindungan terhadap hak-hak asasi manusia, maka dalam UUD NRI Tahun 1945 akan selalu memuat kekuatan mengenai hal ini. Dalam sejarah pemikiran negara dan hukum menunjukkan bahwa negara selalu dikonotasikan sebagai suatu lembaga yang mempunyai keabsahan untuk memaksakan kehendak kepada warga negaranya.(Handoyo, 2003:272)

Konstitusi dibentuk sejatinya adalah untuk membatasi kekuasaan, agar tidak diterapkan secara sewenang-wenang. Dengan demikian pengaturan mengenai HAM akan selalu disejajarkan dengan materi-materi lain di dalam suatu konstitusi negara, bahkan salah satu ciri dari negara hukum adalah adanya jaminan hak-hak asasi manusia, di samping pemisahan kekuasaan, legalitas pemerintahan, dan peradilan yang bebas.

Tindak pidana korupsi merupakan masalah yang sangat serius (Extra Ordinary Crime), karena tindak pidana korupsi dapat membahayakan stabilitas dan keamanan negara sertamasyarakatnya, membahayakan pembangunan sosial dan ekonomi masyarakat, politik, bahkan dapat pula merusak nilai-nilai demokrasi serta moralitas bangsa. Undang-Undang Nomor 30 Tahun 2002 tentang Komisi Pemberantasan Tindak Pidana Korupsi memberikan tugas kepada Komisi Pemberantasan Korupsi (KPK) untuk melakukan penyelidikan, penyidikan dan penuntutan terhadap tindak pidana korupsi. Tugas KPK lainnya adalah koordinasi dengan instansi yang berwenang melakukan pemberantasan tindak pidana korupsi, supervisi terhadap instansi yang berwenang melakukan pemberantasan tindak pidana korupsi, melakukan tindakan-tindakan pencegahan tindak pidana korupsi, dan melakukan monitor terhadap penyelenggaraan pemerintahan negara.

Di dalam KUHAP dibedakan institusi yang berwenang melakukan penyelidikan, penyidikan dan penuntutan, sedangkan Undang-Undang Nomor 30 Tahun 2002 tentang Komisi Pemberantasan Tindak Pidana Korupsi menyatukannya di dalam Institusi tersebut. KPK tidak berwenang mengeluarkan surat perintah penghentian penyidikan dan penuntutan dalam perkara tindak pidana korupsi (Pasal 40). Tidak disebutkan dalam undang-undang bahwa apabila 
bukti permulaan yang cukup telah terpenuhi maka seseorang akan otomatis menjadi tersangka, yang disebutkan adalah jika penyelidik dalam melakukan penyelidikan menemukan bukti permulaan yang cukup adanya dugaan tindak pidana korupsi, dalam waktu paling lambat 7 (tujuh) hari kerja terhitung sejak tanggal ditemukan bukti permulaan yang cukup tersebut penyelidik melaporkan kepada KPK (Pasal 44). Dalam hal seseorang ditetapkan sebagai tersangka oleh $\mathrm{KPK}$, terhitung sejak tanggal penetapan tersebut prosedur khusus yang berlaku dalam rangka pemeriksaan tersangka yang diatur dalam peraturan perundangundangan lain tidak berlaku berdasarkan undang-undang ini (Pasal 46).

Ada beberapa perkara tindak pidana korupsi terkait penetapan status sebagai tersangka menjadi persoalan bila dipandang dari perspektif perlindungan HAM dan kepastian hukum, yaitu mengenai lamanya waktu status tersangka yang dialami dan proses penetapan status tersangka, seperti yang diketahui, mengenai perkara tindak pidana korupsi bekas Direktur Pengolahan PT Pertamina (Persero) Suroso Atmo Martoyo (SAM), SAM ditetapkan sebagai tersangka oleh KPK pada Bulan November 2011, diduga oleh KPK mengenai suap pengadaan zat tambahan bahan bakar TEL (tetraethyl lead) 2004-2005. SAM disangka mengantungi duit suap dari Direktur PT Soegih Indrajaya, Willy Sebastian Liem. Atas perbuatan tersebut, SAM sebagai penerima suap disangka melanggar Pasal 12 huruf a dan atau Pasal 11 Undang-Undang Pemberantasan Tindak Pidana Korupsi. Sementara Willy sebagai pihak pemberi suap disangka melanggar Pasal 5 ayat (1) huruf a dan b dan atau Pasal 13 Undang-Undang Pemberantasan Tindak Pidana Korupsi. Status tersangka yang disandang oleh SAM baru diupayakan penyelesaian melalui jalur praperadilan oleh tersangka dan kuasa hukumnya pada bulan April tahun 2015, seiring dengan upaya jalur praperadilan yang hendak ditempuh, penyidik menyatakan berkas perkara SAM telah dinyatakan lengkap (P21) dan akan segera disidangkan.

Kasus Korupsi Hibah Persiba Bantul oleh Idham Samawi (IS), IS diduga terkait dana hibah Komite Olahraga Nasional Indonesia (KONI) untuk klub sepakbola Persiba Bantul sebesar Rp12,5 miliar. Kasus ini berawal dari laporan LPH Yogyakarta tentang adanya dugaan penyimpangan dana hibah dan Bansos DPRD Yogyakarta 2012-2013 sebesar Rp181,5 miliar. IS sudah ditetapkan sebagai tersangka dalam kasus ini pada akhir tahun 2013, tetapi dalam prosesnya IS tidak ditahan dan berkasnya belum dilimpahkan ke pengadilan oleh Kejaksaan tinggi DIY. Pada tanggal 4 Agustus 2015 Kejaksaan Tinggi Daerah Istimewa Yogyakarta (Kejati DIY) resmi mengeluarkan Surat Perintah Pemberhentian Penyidikan (SP3) untuk kasus korupsi ini. Kepala Kejaksaan Tinggi DIY I Gede Sudiatmaja mengatakan, "Kejati mengeluarkan SP3 karena tidak ditemukannya alat bukti yang 
cukup terhadap IS". SP3 itu diterbitkan Kejati dengan nomor Print369/0.4/Fd.1/08/2015.

Mengenai penetapan status Dahlan Iskan (DI) sebagai tersangka dalam kasus tindak pidana dugaan korupsi pembangunan 21 gardu induk di Jawa, Bali, dan Nusa Tenggara Barat pada periode 2011-2013 Senilai Rp1,063 triliun. Kejaksaan Tinggi DKI Jakarta mengusut kasus ini sejak Juni 2014 setelah menerima laporan audit Badan Pengawasan Keuangan dan Pembangunan (BPKP) terhadap proyek gardu listrik. BPKP dalam auditnya menyebutkan bahwa proyek tersebut diduga merugikan negara sebesar Rp33 miliar. Menurut kejaksaan, penyimpangan ditemukan antara lain ketika penandatanganan kontrak pembangunan gardu induk pada tahun 2011, tetapi lahannya belum dibebaskan. DI dan kuasa hukumnya mengajukan gugatan praperadilan pada Pengadilan Negeri Jakarta Selatan, menyatakan bahwa DI terlebih dahulu ditetapkan sebagai tersangka baru kemudian dicari alat buktinya. Padahal untuk bisa menetapkan seorang tersangka seharusnya sudah ada dua alat bukti yang cukup. Hakim tunggal Lendriaty Janis memutuskan untuk mengabulkan seluruhnya gugatan praperadilan DI terhadap Kejaksaan Tinggi DKI Jakarta, bahwa pengadilan sependapat dengan pihak pemohon DI yang menilai bahwa surat perintah penyidikan atas DI tidak sah dan tidak berkekuatan hukum mengikat.

Pada saat KUHAP diberlakukan pada tahun 1981, penetapan status tersangka belum menjadi isu krusial dan problematik dalam kehidupan masyarakat Indonesia. Upaya paksa pada masa itu secara konvensional dimaknai sebatas pada penangkapan, penahanan, penyidikan, dan penuntutan, namun pada masa sekarang bentuk upaya paksa telah mengalami berbagai perkembangan yang salah satu bentuknya adalah "penetapan tersangka oleh penyidik" yang dilakukan oleh negara dalam bentuk pemberian label atau status tersangka pada seseorang tanpa adanya batas waktu yang jelas, sehingga seseorang tersebut dipaksa oleh negara untuk menerima status tersangka tanpa tersedianya kesempatan baginya untuk melakukan upaya hukum dalam menguji legalitas dan kemurnian tujuan dari keadilan, kepastian, dan kemanfaatan. Dengan kata lain, prinsip kehati-hatian haruslah dipegang teguh oleh penegak hukum dalam menetapkan seseorang menjadi tersangka.

Pasal 28D ayat (1) UUD NRI Tahun 1945 yaitu setiap orang berhak atas pengakuan, jaminan, perlindungan, dan kepastian hukum yang adil serta perlakuan yang sama di hadapan hukum. Sekalipun kita menginsafi bahwa tujuan tindakan penegakan hukum untuk mempertahankan dan melindungi kepentingan masyarakat, penegak hukum tidak boleh mengorbankan hak dan martabat tersangka, atau juga sebaliknya, demi untuk melindungi dan menjunjung harkat dan martabat tersangka tidak boleh dikorbankan kepentingan masyarakat / negara. Harus mampu meletakkan asas keseimbangan yang telah digariskan KUHAP, sehingga antara dua kepentingan yang harus dilindungi oleh hukum sama-sama 
tidak dikorbankan, dan sesuai dalam Pasal 18 ayat (1) Undang-Undang Nomor 39 Tahun 1999 tentang HAM bahwa setiap orang yang ditangkap, ditahan, dan dituntut karena disangka melakukan sesuatu tindak pidana berhak dianggap tidak bersalah, sampai dibuktikan kesalahannya secara sah dalam suatu sidang pengadilan dan diberikan segala jaminan hukum yang diperlukan untuk pembelaannya sesuai dengan ketentuan peraturan perundang-undangan.

Kembali kepada pokok tulisan ini, mengingat penetapan seseorang menjadi tersangka tidak ada batas waktunya, maka adalah penting untuk menjamin dan melindungi hak-hak asasi manusia, keadilan, dan kepastian hukum kepada tersangka. Dengan adanya aturan yang mengikat dan memberi akibat hukum baik terhadap para penegak hukum, dan instansinya, itulah juga salah satu implementasi dari kepastian hukum dan esensi asas praduga tak bersalah.

\section{Korupsi Politik dalam Korelasinya dengan Hak Asasi Manusia}

Pemerintah RI (Orde Lama, Orde Baru) sangat alergi terhadap konvensikonvensi Internasional, misalnya konvensi tentang hak-hak sipil, politik dan ekonomi. Dalam kondisi yang demikian, bangsa Indonesia menjadi miskin dalam wacana hak asasi manusia. Sehingga penguasa menjadi leluasa mempraktekkan keculasan politik dan ekonomi tanpa terkontrol oleh hukum. Sehingga hukum hanya menjadi administrasi untuk melegitimasi praktek kesewenangan ekonomi (korupsi), kesewenangan politik (tirani), dan hubungan gelap transaksional (kolusi) pemegang kekuasaan dan pemilik modal. Produk undang-undang yang dihasilkan oleh legislatif hasil struktur politik dan Pemilu yang tidak demokratis, akan menghasilkan undang-undang yang jelek kualitasnya, seperti halnya UU Parpol/Golkar, UU Pemilu produk Orde Baru, dan lain sejenisnya. Dalam arti pula, keberadaan hukum yang korup merupakan konsekuensi dari sistem politik yang tidak demokratis.

Proses pelaksanaan demokrasi akan tampil secara angkuh, manakala sendi-sendinya tidak diberi minyak pelumas hukum yang adil, tetapi hanya ditopang oleh kekuatan fisik (militer, penggalangan massa), tanpa nurani kebenaran moral. Dan hukum yang dikedepankan adalah hukum yang represif seperti antara lain UU Subversi UU No. 11/1963. Undang-undang ini termasuk salah satu aturan hukum pidana di bidang tindak pidana politik yang dalam prakteknya telah banyak membelenggu hak-hak politik rakyat selama Orla dan Orba seperti mahasiswa, intelektual, dan tokoh-tokoh Islam yang kritis. Perangkat hukum keras (hard law) ini, menjadi bagian dari "kultur politik" selama Orde Baru dan sangat efektif dijadikan instrumen permainan kuasa suatu rezim kekuasaan. Sebaliknya sosok penampilan demokrasi akan terlihat anggun (elegant) dan bermartabat, apabila ditopang oleh hukum yang substansinya adalah nilai-nilai kebajikan dan keadilan. 
Jatuhnya rezim Soeharto yang pekat dengan praktek korupsi politik yang bercorak KKN (Korupsi, Kolusi, Nepotisme), membuka peluang bagi munculnya banyak media cetak dan elektronik. Media cetak yang selama berkuasanya rezim Soeharto tersumbat aspirasi dan eksistensinya, mendapatkan iklim politik yang memungkinkan bagi kebebasan pers. Pada saat yang sama munculnya banyak media pers ini memikul tanggung jawab moral untuk melakukan kontrol terhadap praktek korupsi. Apakah dengan banyaknya pers secara kuantitas berarti makin efektif pula kontrol sosial terhadap penyimpangan pelaksanaan kekuasaan. Dalam kenyataannya jumlah penerbitan media massa di Indonesia meningkat tajam setelah jatuhnya rezim korup Orde Baru. Sejak lengsernya Soeharto, Menteri Penerangan telah meloloskan (menyetujui) hampir 1000 izin baru. Hal ini menambah sekitar 200-300 penerbitan yang telah ada pada masa Orde Baru. Dari melonjaknya jumlah penerbitan media seperti yang ditunjukkan John Olle tersebut di atas tidak ternyata ada pengaruh kontrol sosial yang signifikan terhadap penurunan praktek korupsi di Indonesia hingga tahun 2004. Hal ini menunjukkan bahwa kuantitas mass media tidak otomatis mempengaruhi jumlah kasus korupsi yang terjadi di masyarakat.(Pro Justisia, 2008)

Dalam reformasi hukum pidana, hendaknya diingat bahwa kejahatan politik tidak hanya dilakukan oleh individu atau organisasi melawan pemerintah, terutama yang mencoba mengubah sistem politik dan melawan hukum, tetapi juga kejahatan politik yang dilakukan oleh pemerintah melawan rakyat, misalnya kerahasiaan dan nasehat yang dipergunakan aparat pemerintahan untuk memanipulasi opini publik, misalnya tentang masalah kontroversi proses kelahiran Supersemar, dan bahkan saat ini tidak jelas keberadaannya, hilang atau dihilangkan, aparat negara yang mana yang harus bertanggung jawab yang dipermasalahkan oleh banyak orang. Juga penyalahgunaan kekuasaan oleh aparat pemerintah, juga yang berhubungan dengan tahanan politik, dan hubungannya dengan konvensi-konvensi Internasional dan ekstradisi yang kesemuanya itu dituntut untuk diformulasikan dengan proses yang demokratis, substansi yang bersifat kerakyatan, konstruksi hipotesis pasal aturan hukum yang yuridis, bukan konstruksi politis seperti UU Subversi. Di samping kemandirian lembaga peradilan dan adanya kontrol sosial politik yang kondusif, dan formulasi hukum pidana bidang politik.

Korupsi politik berkorelasi dengan penegakan HAM, karena makin korup suatu rezim pemerintahan akan makin represif karakter pemerintahannya yang pada saat yang sama penguasa akan banyak mengabaikan kaidah hukum dan melanggar hak-hak asasi rakyatnya.

Pengadilan HAM di Indonesia merupakan salah satu bagian dari Sistem Peradilan di Indonesia. Pengadilan HAM memiliki tugas penting untuk membangun rasa kepercayaan rakyat Indonesia dan komunitas internasional tentang kedaulatan dan kepastian hukum di Indonesia saat ini. Pengadilan 
merupakan pelantar (agent) dari peradaban, demokratisasi dan pembebasan. Proses pengadilan yang anggun dan kredibel akan mentranformasikan nilai-nilai kemanusiaan dan memberikan pesan pendidikan nurani bagi bangsa manusia. Proses peradilan merupakan interaksi naluri kemanusiaan dan akal sehat. Nilai kemanusiaan sebagai anugerah dari Allah Yang Maha Kuasa merupakan sesuatu yang sakral. Untuk itu pengadilan di Indo-nesia harus mampu meningkatkan penghargaan terhadap martabat manusia, integritas nasional dan kepercayaan internasional. Eksistensi dan peran pengadilan HAM adalah menghargai nilai kemanusiaan, hak-hak korban, hak-hak pelaku, sensitivitas sosial dan moralitas universal.

Timbulnya korupsi dan kejahatan HAM tidak lepas dari kekuasaan yang tidak terkontrol atau penyalahgunaan kekuasaan. Dalam hal ini menurut Muladi, mengingat seringnya dikatakan bahwa sumber atau kesempatan korupsi adalah pemberian monopoli kekuasaan kepada seseorang atau lembaga disertai dengan kewenangan untuk melakukan diskresi secara luas (perpajakan, bea cukai, penegakan hukum, imigrasi), maka harus ada pengawasan dan pengendalian yang ketat terhadap kewenangan monopolistik dan diskresioner tersebut.18 Kebutuhan akan adanya kontrol terhadap kekuasaan agar dapat merespon terhadap praktek korupsi dan kejahatan HAM adalah masyarakat madani yang kuat, pers yang proporsional, perguruan tinggi yang memiliki integritas, LSM yang kuat dan organisasi sosial keagamaan yang responsif.

Rezim Orde Baru tidak lepas dari keterkaitannya dengan korupsi politik dan pelanggaran HAM, karena presiden dan aparatnya dalam beberapa kasus telah diindikasikan, disangka, didakwa dan dipidana. Dalam hubungannya dengan Pengadilan HAM di Indonesia, Muladi berpendapat, secara sistemik Indonesia telah menggelar Pengadilan HAM Timor Timur dan Pengadilan HAM yang lain (Tanjung Priok), yang terjadi di masa sebelum UU No. 26 Tahun 2000 diundangkan. Langkah-langkah dilakukan secara sistemik karena Pengadilan HAM harus mengadili "extra ordinary crime" maka tidak diizinkan untuk menggunakan perumusan "ordinary crimes" yang sudah diatur dalam hukum nasional (KUHP dll); untuk itu dengan metode "partial harmonization," dalam UU No. 26 Tahun 2000 diadopsi perumusan tindak pidana, khususnya yang menyangkut "genocide" dan "crimes against humanity" dan beberapa ketentuan lain yang diambil dari Statuta Roma tahun 1998. Hal ini dilakukan karena Indonesia belum meratifikasi statuta tersebut.19 Korupsi politik dan pelanggaran HAM secara terkait juga dilakukan oleh pemimpin negara seperti Soeharto, Marcos, Reza Pahlevi, Pinochet, dan lainlain.

Hahn Been Lee (dalam Susilo Zauhar, 1996) mengkategorikan reformasi ke dalam 3 (tiga) agenda yaitu: (JIAKP, 2007:23-41) 
a. Reformasi tatananReformasi Prosedur Masyarakat tradisional maupun modern sangat menyukai keteraturan, terlebih lagi pada masyarakat transisional (prismatic) yang sedang melakukan reformasi besarbesaran. Pada situasi ini, masyarakat suka bernostalgia pada tatanan lama. Untuk menanggulangi masalah tersebut reformasi perlu diarahkan pada penciptaan prosedur dan membangun rutinitas. Reformasi harus diorientasikan pada penataan prosedur dan kontrol untuk menghadang agen pembaharu agar pembaharuan tidak menimbulkan kekacauan.

b. Reformasi Metode Reformasi Teknik Penyempurnaan tatanan merupakan produk dari kekacauan, sedangkan dorongan untuk menyempurnakan metode timbul karena Pemberantasan Korupsi di Indonesia juga karena adanya stimulan dari masyarakat. Apabila masyarakat semakin mendukung adanya administrator teknis daripada status maka administrator harus fanatik pada metode. Administrator publik dalam masyarakat yang sudah maju secara teknologi dituntut semakin fanatik pada perkembangan teknik dan metode.

c. Reformasi Unjuk kerja Reformasi Program Penyempurnaan unjuk kerja lebih bernuansa tujuan dalam substansi program kerjanya daripada penyempurnaan keteraturan maupun penyempurnaan metode teknis administratif. Fokus utamanya adalah pergeseran dari bentuk ke substansi, dari efisiensi dan ekonomis ke efektivitas kerja, dari kecakapan birokrasi ke kesejahteraan masyarakat. Bukan hanya bertujuan pada hukum dan ketertiban atau prosedural, atau pencarian metode dan teknik baru, tetapi berfokus pada keluaran.

\section{KESIMPULAN}

Uraian diatas menegaskan bahwa ada kaitan yang erat antara perwujudan Negara Hukum yang Demokratis dengan kejahatan korupsi dan pelanggaran HAM. Ketidakmampuan mewujudkan Negara Hukum yang Demokratis dalam bentuk yang sekongrit-kongkritnya akan dapat menyebabkan tindak korupsi dan pelanggaran HAM tidak dapat ditangani sepenuh-penuhnya. Tindak korupsi mempunyai kaitan dan bahkan juga dapat menjadi bagian serta dikualifikasi sebagai kejahatan hak asasi manusia karena dampak clan tindak pidana korupsi dapat menyebabkan diingkari, dicampakkan dan dirampasnya "human dignity".( PRIORIS , 2012) Korupsi menjadi salah satu penyebab negara belum mampu memenuhi kewajibannya untuk belum mampu memenuhi kewajibannya untuk menjamin pemenuhan hak asasi warga negara. Pemberantasan korupsi harus mulai mempertimbangkan perspektif hak asasi warga negara Indonesia dalam rangka mengembalikan negara Indonesia dalam rangka mengembalikan hak-hak ekonomi dan hak sosial yang telah dilanggar selama ini. 


\section{DAFTAR PUSTAKA}

Barat, P. B. (2003). Hak Asasi manusia (Seri Bacaan Hak Asasi Manusia). Bandung. Harahap, M. Y. ( 2002). Pembahsan Permasalahan dan Penerapan KUHAP Penyidikan dan Penuntutan. Jakarta: Sinar Grafika.

Sutandi. (2012). Korupsi dan Hak Asasi Manusia. Jurnal hukum PRIORIS.

Alkostar, A. (2009). "Korelasi Korupsi Politik Dengan Hukum dan penanggulangannya". Jurnal Hukum. Edisi Khusus.

Arief, B. N. (2003). Kapita Selekta Hukum Pidana. Bandung: Citra Aditya Bakti.

Handoyo, B. H. (2003). Hukum Tata Negara, Kewarganegaraan dan Hak Asasi Manusia. Yogyakarta: Universitas Atma Jaya Yogyakarta.

Harahap, M. Y. ( 2002). Pembahsan Permasalahan dan Penerapan KUHAP Penyidikan dan Penuntutan. Jakarta: Sinar Grafika.

Sutandi. (2012). Korupsi dan Hak Asasi Manusia. Jurnal Hukum PRIORIS. Vol. 3(1)

Wulandari, S. (Januari 2008). "Pemberantasan Korupsi di Indonesia". Jurnal Hukum Pro Justisia, Vol.26 No.1. 